\title{
DISSERTAÇÕES
}

\section{A classe trabalhadora frente às mudanças no perfil do assalariamento no Brasil}

Rita Matos Coitinho

Curso: Mestrado em Sociologia

Data: 6 de dezembro de 2007

Orientador: Prof. Dr. Sadi Dal Rosso

\section{Resumo}

O presente trabalho discute a atualidade e a aplicabilidade do conceito de classes sociais para a análise da sociedade brasileira contemporânea e procura demonstrar quem são os componentes da classe trabalhadora na atualidade.

Em um primeiro momento, a partir da discussão de textos sociológicos clássicos e contemporâneos, procuramos encontrar um modelo adequado ao estudo das classes sociais no Brasil. Nosso entendimento foi de que as classes sociais definem-se pelas relações de produção, ou, mais precisamente, pela posição ocupada na divisão social do trabalho. Em relação à classe trabalhadora, consideramos a necessidade de se pensar o conceito de forma ampliada, de modo a abarcar a totalidade dos indivíduos cuja sobrevivência depende exclusivamente da venda da sua força de trabalho e da de seus familiares, aí incluindo-se também o contingente de pessoas desempregadas. 
Em um segundo momento mostramos como, historicamente, o Brasil tornou-se um país plenamente capitalista, podendo por isso ser estudado a partir do instrumental sociológico construído para a análise dessa formação social, particularmente com base no entendimento de que são duas as classes mais importantes nas sociedades capitalistas: a classe dos capitalistas e a classe dos trabalhadores.

Com o objetivo de chegar a uma delimitação mais aproximada da classe trabalhadora brasileira, elegemos o assalariamento como principal objeto de análise. Na análise de duas décadas (1980 e 2000), feita com base nos dados dos censos do IBGE, observamos que o assalariamento é o principal meio de inserção dos brasileiros no mundo do trabalho e que o emprego industrial vem perdendo espaço para o setor terciário. Por conta disso ganha relevância o entendimento de que o conceito de classe trabalhadora transborda os limites do trabalho fabril, abarcando todas as formas de trabalho assalariado, da mesma maneira como o capital se expande para os mais diversos tipos de atividade econômica.

Nossa conclusão aponta para a permanência da centralidade do trabalho assalariado no Brasil contemporâneo e mostra que as mudanças ocorridas nas últimas décadas tornaram mais complexa a análise da classe trabalhadora, uma vez que esta se encontra mais fragmentada.

Palavras-chave: classes sociais, classe trabalhadora, assalariamento. 